\title{
KONSEP DASAR BELAJAR DI SDIT CENDIKIA
}

\author{
Nurul Maspupah \& Nurhaeniah \\ Universitas Muhammadiyah Tangerang \\ nurul.maspupah@umt.ac.id,nurhaeniah@umt.ac.id
}

\begin{abstract}
The purpose of this study is to find out the meaning of learrning, this study uses a qualitative approach, tiben the instruments used are observation and documention of learning activities in class.the results of the analysis of student learning are obtained $i$ the cognitive shutter which is the value of student evaluations when working on evaluation questions given by the teacher when the learning process takes place. The results of this study can be used SDIT CENDIKIA to find out learning styles of student learning outcomes and can be used for consideration of schools and parents of students, especially those in grades $V$ and VI
\end{abstract}

Keywords: Learning, Learning Outcomes

\begin{abstract}
Abstrak : Tujuan dari penelitian ini untuk mengetahui arti pembelajaraan, Penelitian ini menggunakan pendekatan kualitatif, lalu instrumen yang digunakan adalah observasi dan dokumentasi kegiatan belajar dikelas, hasil dari analisis belajar siswa di peroleh pada rana kognitif, yaitu pada nilai evaluasi siswa pada saat mengerjakan soal evaluasi yang di berikan oleh guru saat proses kegiatan belajar mengajar berlangsung. Hasil penelitian ini dapat digunakan SDIT CENDIKIA untuk mengetahui gaya belajar terhadap hasil belajar siswa serta dapat digunakan untuk pertimbangan sekolah serta orangtua siswa untuk memperbaiki perhatian terhadap siswa terutama yang berada di kelas V dan VI
\end{abstract}

Kata Kunci : Pembelajaran, Hasil Belajar

\section{PENDAHULUAN}

Pada Hakikatnya kegiatan belajar mengajar adalah suatu proses komunikasi harus diciptakan atau diwujudkan melalui kegiatan penyampaian dan tukar menukar pesan dan informasi antara pendidik dan peserta didik. Satu kesatuan dari proses komuniksi belajar mengajar yang bertumpu pada tujuan pendidikan disekolah adalah media pembelajaran peranan media pembelajaran pun menjadi penting karena memiliki nilai praktis dan fungsi besar dalam pelaksanaan pembelajaran, proses pembelajaran merupakan tahapan tahapan yang dilalui dalam mengembangkan kemampuan 
kognitif, afektif dan dimiliki dan psikomotorik seseorang dalam hal ini adalah kemampuan yang harus dimiliki seorang siswa atau peserta didik salah satu peran yang dimiliki oleh seorang guru untuk melalui tahap tahap ini adalah sebagai fasilitator. Untuk menjadi fasilitator yang baik guru harus berupaya dengan optimal mempersiapkan rancangan pembelajaran yang sesuai dengan karakteristik anak, demi mencapai tujuan pembelajaran. Menurut Nana sudjana (2010, hlm 5 ) menyebutkan bahwa " belajar suatu proses yang ditandai dengan adanya perubahanpada diri seseorang. Perubahan sebagai penghsilan dari proses belajardapat ditunjukan dalam berbagai bentuk seperti berubah pengetahuan, pemahaman sikap dan tingkah laku, keterampilan, kecakapan, kebiasaan, serta perubahan aspek-aspek lain yanng ada pada individu yang belajar”.

\section{METODE PENELITIAN}

\section{Jenis Penelitian}

Penelitian ini menggunakan jenis penelitian kualitatif studi kasus. Dalam penelitian ini, mengumpilkan data deskriptif yang diperoleh dari pengumpulan data dengan melalui observasi,wawancara, dan dokumentasi.

\section{Waktu dan Penelitian tempat}

Penelitian ini dilaksanakan di SDIT GLOBAL CENDIKIA, pada hari jumat tanggal 15 november yang beralamat kp. Doyong Rt 05/15 kelurahan gembor kecamatan periuk kota tanggerang pada tahun 2019/2020, lokasi tersebut dipilih karna berdasarkan pertimbangan penelitian karena pengembangan bahan ajar disekolah cukup berkembang dan mengikuti era globalisasi.

\section{Target/subjek Penelitian}

Subjek dalam penelitian ini adalah siswa dan guru yang mengajar di SDIT GLOBAL CENDIKIA. Guru kelas dijadikan penelitian utama dan siswa yang kedua, selain itu guru kelas juga dipandang sebagai orang yang benar-benar mengetahui perkembangan bahan ajar. Selain itu, guru kelas juga dipandang sebagai orang yang benar-benar mengetahui tentang perkembangan bahan ajar di sekolah. 


\section{Prosedur}

Penelitian ini menggunakan tipe penelitian kualitatif. Data diperoleh melalui proses observasi, wawancara dan dokumentasi. Dari pengumpulan informasi melalui observasi, wawancara dokumentasi dan catatan lapangan, kemudian penyimpulan pengatasan dan penyimpulan hasil.

\section{Data, Intrumen, dan Teknik pengumpulan data}

Teknik pengumpulan data dalam penelitian menggunakan teknik observasi, wawancara, dokumentasi, cacatan lapangan. Teknik pengumpulan data dalam penelitian ini dengan melakukan wawancara terhadap guru kelas V. Peneliti juga melakukan dokumentasi dan membuat catatan lapangan sebagai upaya untuk kelengkapan data. Selain itu penelitian juga menggunakan kuesioner yang dilakukan dengan cara memberi seperangkat pernyataan tertulis kepada responden yaitu guru kelas V di SDIT GLOBAL CENDEKIA.

\section{Teknik Analisis Data}

Teknik data dilakukan sesuai dengan prosedur ilmiah penelitian kualitatif. Paada penelitian ini menggunakan metode analisis dari Milles dan Huberman. Dalam teknik analisis ini terdapat tiga tahap yaitu redksi data, penyajian data, dan verifikasi data. Reduksi data bertujuan untuk menyederhanakan data yang abstrak menjadi sebuah rangkuman yang jelas dan terperinci. Data tersebut dihasilkan dari proses observasi, wawancara, dokumentasi. Proses selanjutnya adalah penyajian data. Setelah direduksi kemudian dat di sajikan kedalam bentuk yang lebih sederhana dalam bentuk paparan naratif dan hasil penelitian tentang pengembangan bahan ajar. Kemudian langkah terakhir adalah verifikasi data.

\section{HASIL PENELITIAN DAN PEMBAHASAN}

Sebelum guru menyampaikan materi berikutnya,guru memberikan suatu stimulus yang relevan dengan materi pembelajaran untuk mengaktifkan pengetahuan sebelumnya dengan cara mengaktifkan skema dengan organisator awal. Cara ini digunakan untuk mengarahkan peserta didik pada materi yang akan dipelajari dan 
membantu mengingat informasi terkait, yang dapat membantu menyatukan informasi tersebut, dengan memberikan pertanyaan-pertanyaan pengait.

Kemudian guru menyampaikan metode yang akan digunaka, dengan memberikan penejalsan singkat mengenai materi yang akan dipelajari melalui media berupa video maupun gambar. Tujuan guru menggunakan metode ini, agar peserta didik secara aktif mengembangkan potensi dirinya.

Sesuai dengan teori kognitif, belajar dipandang sebagai suatu usaha untuk mengerti tentang sesuatu. Usaha untuk mengerti sesuatu tersebut, dilakukan secara aktif oleh sipelajar. Keaktifan tersebut dapat berupa mencari pengalaman, mencari informasi, memecahkan masalah, mencermati lingkungan, mengolah stimulus yang bermakna dan mengabaikan yang tidak bermakna untuk mencapai tujuan belajar. Salah satu teori belajar yang berasal dari psikologi kognitif adalah teori pemrosesan informasi. Menurut teori ini, belajar dipandang sebagai proses pengolahan informasi dalam otak manusia. Menurut teori ini suatu informasi atau stimulus yang berasal dari lingkungan,pada awalnya diterima oleh reseptor. Reseptor-reseptor tersebut memberikan simbol-simbol informasi yang diterima, dan kemudian diteruskan ke registor penginderaan telah mengalami transformasi.

Setelah guru menyampaikan materi yang akan dipelajari, kemudian guru melihat respon peserta didiknya dengan memantau setiap prosesnya serta menanyakan kesulitan yang dihadapi siswa. Apabila respon peserta didik terhadap guru yang mengajar di dalam kelas positif, maka metode yang digunakan guru tersebut berhasil. Karena guru menerapkan pembelajaran berupa membagi siswa kedalam beberapa kelompok serta membgi materi sesuai jumlah kelompok, setelah itu guru memberikan waktu kepada siswa unutk berdiskusi dengan teman sekelompoknya sebelum di presentasikan di depan kelas. Tujuan guru menerapkan pemebelajaran tersebut supaya pesert didik merasa tercukupi dari segi pembelajaran maupun pemahaman.

Dalam menerapkan pembelajaran yang sesuai dengan metode yang digunakan oleh guru, guru hendaknya mempersiapkan segala sesuatunya agar pembelajaran tersampaikan dengan maksimal. Guru hendaknya mempersiapkan materi yang akan disampaikan secara tersusun dan terarah supaya peserta didik dapat 
memahami dan menangkap metode pembelajaran yang diterapkan oleh guru di dalam kelas.

Dalam konteks berpikir demikian, bruner berpendapat bahwa pembelajaran dapat dilakukan kapan saja tanpa harus menunggu seorang anak sampai mencapai tahap perkembangan tertentu. Apabila bahan atau materi pembelajaran didesain secara baik, maka individu dapat belajar meskipun usahanya belum memadai. Dengn logika lain, perkemangan kognitif seseorang dapat ditingkatkan melalui materi yang dirancang sesuai dengan karakterisitik kultural peserta didik.

Serta penguasaan kelas harus dimiliki oleh guru, karena disitulah guru dapat melihat setiap kemampuan yang dimiliki oleh setiap siswa. Teori belajar bruner disebut dengan discovery learning, yaitu dimana peserta didik mengorganisasi bahan yang dipelajari dengan suatu bentuk akhir. Prosedur ini berbeda dengan reseption liming atau expository teaching, dimana guru harus menerapkan informasi dan murid harus mempelajari semua bahan/informasi itu. Dengan seperti itu, guru dapat memantau setiap tindakan yang dilakukan oleh setiap siswanya serta dapat mengetahui kemampuan anak dalam memahami materi pembelajaran yang telah diberikan. Secara logika, guru tersebut dapat menguasai kelas dengan baik tanpa perlu menerangkan setiap materi/informasi kepada peserta didik. Peserta cukup dijelaskan maksud dari pembelajaran serta materi yang akan disampaikan setelah itu peserta didiklah yang akan mengorganisasi bahan yang kan dipelajari dengan suatu bentuk akhir. Kemudia guru memantau setiap tindakan yang dilakukan oleh setiap siswanya dan menanyakan kesulitan yang dihadapi siswa dengan menjelaskan kembali diakhir pembelajaran.

Setelah metode yang digunakan guru dalam menyampaikan materi pembelajaran didalam kelas tersampikan, kemudian hendaknya guru memperhatikan peran serta peserta didik dan memahami materi yang diberikan didalam kelas. Guru mengutamakan peran peserts didik dalam berinteraksi aktif sendiri dan keterlibatan aktif dalam kegiatan belajar. Dalam kelas, piaget menekankan bahwa pengajaran pengetahuan jadi (ready made knowledge), anak didorong menentukan sendiri pengetahuan itu melalui interaksi spontan dengan lingkungan. Kemudian mengutamakan peran peserta didik dalam berinteraksi, pertukran gagasan-gagasan 
tidak dapat dihindari untuk perkembangan penalaran. Walaupun penalaran tidak dapat mereka sajikan secara langsung, perkembangannya dapat disimulasi.

\section{KESIMPULAN}

Guru menerapkan metode pemelajaran yang sesuai dengan teori belajar menurut pandangan kognitif. Karena teori belajar kognitif lebih mementingkaan proses belajar daripada hasil belajarnya. Teori ini juga menekankan bahwa bagianbagian dari suatu situasi saling berhubungan dengan seluruh konteks situasi tersebut. Membagi-bagi situasi/materi pelajaran menjadi komponen-komponen kecil dan mempelajarinya secara terpisah akan menghilangkan makna belajar.

Teori ini juga berpandangan bahwa beljar merupakan suatu proses internal yang mencakup ingatan, retensi, pengolahan informasi, emosi, dan faktorfaktor lain. Belajar adalah aktifitas yang melibatkan proses berpikir yang sangat kompleks. Proses belajar disini anatara lain mencakup pengaturan stimulus yang diterima (faktor eksternal) dan menyesuaikan dengan struktur kognitif yang sudah terbentuk didalam pikiran seseorang (badground knowledge) berdasarkan pengalaman-pengalaman sebelumya (faktor internal).

Teori kognitif lebih menekankan pada struktur internal pembelajaran dan lebih memberi perhatian pada bagaimana seseorang menerima, menyimpan, dan mengingat kembali informasi dari perbendaharaan ingatan. Ada beberapa kelompok penganut teori kognitif, namun fokus dari penganut teori ini sama yaitu pada soal bekerjanya pikiran manusia.

\section{DAFTAR PUSTAKA}

Asri budiningsih. 2007. Belajar dan pembelajaran. Jakarta : Rineka cipta.

Karwono dan heni mularsih. 2010. Belajar dan pembelajaran serta pemanfaatan belajar. Ciputat : cerdas jaya

Mukminan, dkk. 1998 belajar dan pembelajaran. Yogyakarta : institut keguruan dan ilmu pendidikan yogyakarta. 